\title{
Child with intestinal volvulus misdiagnosed as diabetic ketoacidosis
}

\author{
Anna Hermine Markowich (D) , ${ }^{1}$ Giulia Nocentini, ${ }^{1}$ Paolo Maria Salvatore Schingo, ${ }^{2}$ \\ Andrea Deidda ${ }^{3}$
}

'University Department of Pediatrics, University of Rome Tor Vergata, IRCCS Bambino Gesù Children's Hospital, Rome, Italy

${ }^{2}$ Department of Diagnostic Imaging, IRCCS Bambino Gesù Children's Hospital, Rome, Italy ${ }^{3}$ Pediatric Emergency Department, IRCCS Bambino Gesù Children's Hospital, Rome, Italy

Correspondence to Dr Giulia Nocentini; giulianocentini@outlook.com

Accepted 15 September 2021

\section{DESCRIPTION}

A 5 -year-old boy was brought to the Emergency Department (ED) because of abdominal pain, nausea and fever. On examination the patient was unwell, mildly tachycardic and tachypnoeic; his abdomen was diffusely tender. Venous blood gas showed metabolic lactic acidosis ( $\mathrm{pH}$ : 7.07, HCO3: $13 \mathrm{mmol} / \mathrm{L}$, lactate: $10.3 \mathrm{mmol} / \mathrm{L}$ ) with hyperglycaemia $(21.5 \mathrm{mmol} / \mathrm{L})$

Based on these findings the boy was diagnosed with diabetic ketoacidosis (DKA) and transferred to our paediatric ED.

On arrival the boy was critically ill, his vitals showed an $\mathrm{SpO}_{2}$ of $70 \%$ on room air, arterial blood pressure of $79 / 50 \mathrm{~mm} \mathrm{Hg}$ and heart rate of 145 bpm. On examination the patient was dyspnoeic, the abdomen distended and diffusely tender with no audible bowel sounds.

Following intubation and stabilisation an abdominal CT was performed (figure 1); it showed small bowel obstruction and superior mesenteric ischaemia. Immediate surgery was performed, revealing midgut volvulus on intestinal malrotation with intestinal necrosis (figure 2), therefore the patient underwent a subtotal small bowel resection with jejunocolic anastomosis, resulting in ultrashort bowel syndrome (residual bowel length $<10 \mathrm{~cm}$ or $<10 \%$ of the expected length for age). ${ }^{1}$

$\mathrm{He}$ was eventually discharged on parenteral nutrition.

Intestinal malrotation results from an abnormal rotation of the embryonic gut; later in life it can cause twisting of the small bowel around the superior mesenteric artery, leading to vascular compromise and eventually necrosis of large portions of the intestine. Clinical manifestations of intestinal malrotation usually occur within the first year of

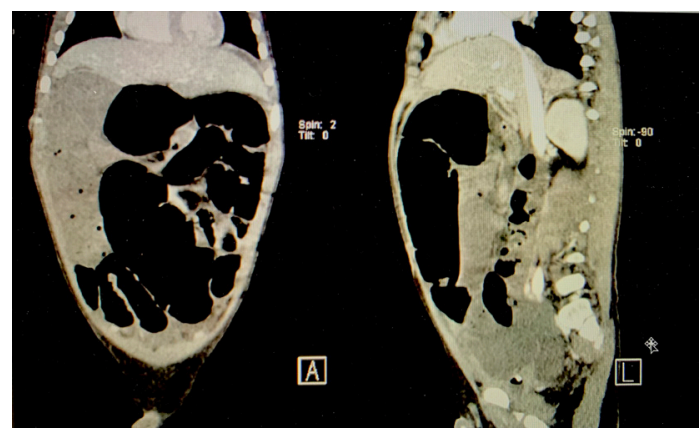

Figure 1 Abdominal CT shows severely dilated ileal loops with air-fluid levels, compatible with small bowel obstruction.

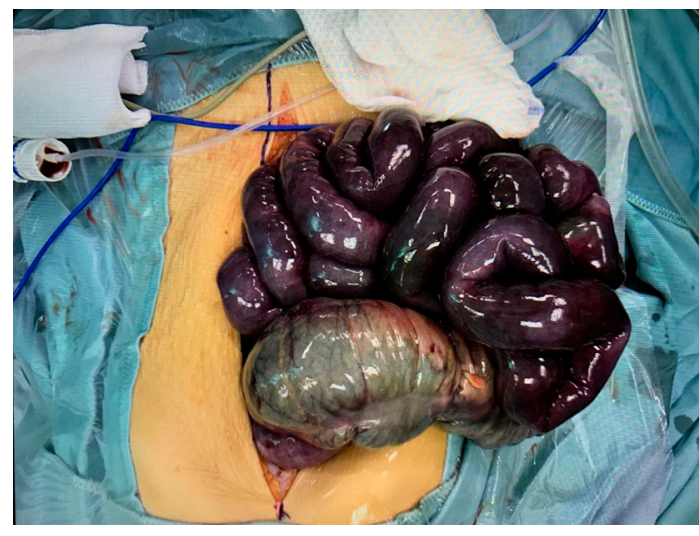

Figure 2 Intraoperative picture of necrotic bowel.

life, but our patient was asymptomatic until 5 years of age.

The diagnosis of volvulus is usually made by abdominal ultrasound, radiograph and, potentially, $\mathrm{CT}^{2}$; treatment consists of immediate laparotomy ${ }^{3}$ and prognosis depends on the time of intervention.

The boy originally presented with mainly abdominal symptoms but, because of the hyperglycaemia, he was mistakenly diagnosed with DKA.

Biochemical diagnostic criteria for DKA are blood glucose $>11 \mathrm{mmol} / \mathrm{L}, \mathrm{pH}<7.3$ or serum bicarbonate $<15 \mathrm{mmol} / \mathrm{L}$, ketonaemia $\geq 3 \mathrm{mmol} / \mathrm{L}$ or moderate-to-large ketonuria. ${ }^{45}$

The patient was not initially tested for ketonaemia or ketonuria.

These simple tests would have allowed to rule out DKA and suspect stress hyperglycaemia, an endogenous response to stressful conditions such as injuries, severe infections or respiratory distress; stress hyperglycaemia results from the interaction between the sympathetic nervous system, proinflammatory

Learning points

Volvulus on intestinal malrotation usually occurs within the first year of life, but it should be considered as a cause of acute abdomen in older children as well.

- When suspecting an intestinal volvulus it is pivotal to promptly obtain diagnostic images to expedite the surgical treatment and improve the outcome.

- Hyperglycaemia is not found exclusively in diabetes, but it can also occur as a systemic stress reaction. 
mediators and the hormones involved in glycogenolysis and gluconeogenesis.

Our patient had a bowel obstruction leading to shock, lactic acidosis and, eventually, metabolic acidosis with extreme stress hyperglycaemia (blood sugar $>16.7 \mathrm{mmol} / \mathrm{L}$ ). The latter is a sign of severe illness and correlates with high mortality. ${ }^{6}$

To conclude DKA should only be diagnosed when all its biochemical features are present; in this case overlooking an acute abdominal emergency because of stress hyperglycaemia led to a disastrous outcome.

Acknowledgements No funding was received for this paper; none of the authors have affiliations to disclose.

Contributors AHM had the idea for the article. GN drafted the article. PMSS performed the literature search and made the radiological diagnosis. AD revised the article critically and provided intellectual content; he also is the guarantor for the article.

Funding The authors have not declared a specific grant for this research from any funding agency in the public, commercial or not-for-profit sectors.
Competing interests None declared.

Patient consent for publication Parents/guardians consent obtained.

Provenance and peer review Not commissioned; externally peer reviewed.

ORCID iD

Anna Hermine Markowich http://orcid.org/0000-0002-7495-5809

\section{REFERENCES}

1 Batra A, Keys SC, Johnson MJ, et al. Epidemiology, management and outcome of ultrashort bowel syndrome in infancy. Arch Dis Child Fetal Neonatal Ed 2017;102:F551-6.

2 Garel C, Blouet M, Belloy F, et al. Diagnosis of pediatric gastric, small-bowel and colonic volvulus. Pediatr Radiol 2016;46:130-8.

3 Spigland N, Brandt ML, Yazbeck S. Malrotation presenting beyond the neonatal period. J Pediatr Surg 1990:25:1139-42.

4 Wolfsdorf Jl, Glaser N, Agus M, et al. ISPAD clinical practice consensus guidelines 2018 : diabetic ketoacidosis and the hyperglycemic hyperosmolar state. Pediatr Diabetes 2018;19 Suppl 27:155-77.

5 Lavoie ME. Management of a patient with diabetic ketoacidosis in the emergency department. Pediatr Emerg Care 2015;31:376-80.

6 Weiss SL, Alexander J, Agus MSD. Extreme stress hyperglycemia during acute illness in a pediatric emergency department. Pediatr Emerg Care 2010;26:626-32.

Copyright 2021 BMJ Publishing Group. All rights reserved. For permission to reuse any of this content visit

https://www.bmj.com/company/products-services/rights-and-licensing/permissions/

BMJ Case Report Fellows may re-use this article for personal use and teaching without any further permission.

Become a Fellow of BMJ Case Reports today and you can:

- Submit as many cases as you like

- Enjoy fast sympathetic peer review and rapid publication of accepted articles

- Access all the published articles

Re-use any of the published material for personal use and teaching without further permission

\section{Customer Service}

If you have any further queries about your subscription, please contact our customer services team on +44 (0) 2071111105 or via email at support@bmj.com.

Visit casereports.bmj.com for more articles like this and to become a Fellow 